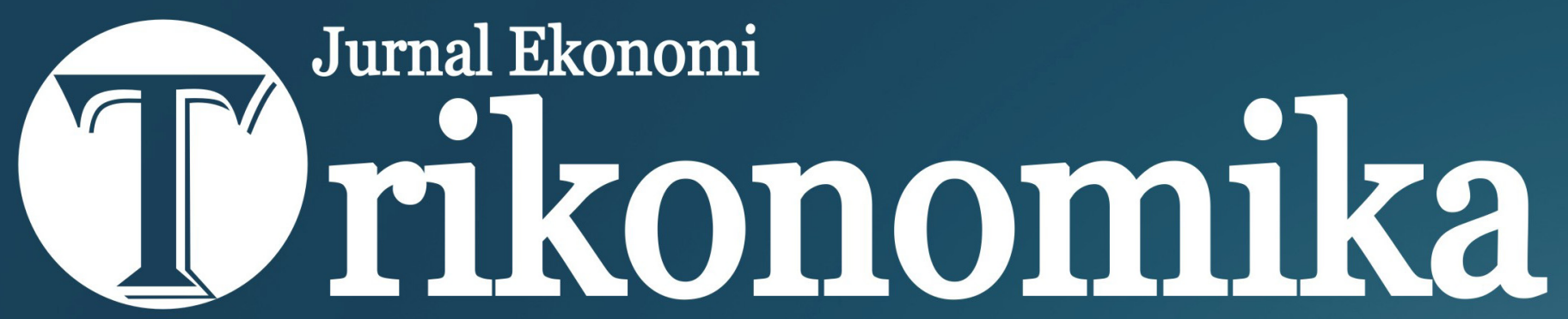




\section{DAFTAR ISI}

Trikonomika, Volume 13, No. 1, Juni 2014

Pengaruh Otonomi dan Akuntabilitas Perguruan Tinggi terhadap Kinerja Manajerial

Isnaeni Nurhayati

Keseimbangan Jangka Pendek dan Jangka Panjang Nilai Tukar Rupiah terhadap Dollar Amerika

Horas Djulius, Yudi Nurdiansyah

Kajian Kepemimpinan Transformasional, Komitmen Karyawan, Motivasi, Kepuasan Kerja, dan Kinerja Karyawan

Edy Saptono $21-48$

Pengaruh Kualitas Pelayanan terhadap Kepuasan Mahasiswa Program Ekstensi Fakultas Ekonomi Universitas Jambi

Yenny Yuniarti $49-61$

Determinan Profitabilitas Bank: Suatu Studi pada Bank yang Terdaftar di BEI

Jaja Suteja, Gerinata Ginting .

Faktor Determinan Minat Wirausaha Mahasiswa Fakultas Ekonomi dan Bisnis Universitas Negeri Gorontalo

Herwin Mopangga $78-90$

Pengaruh Upah dan Pengalaman Kerja terhadap Produktivitas Karyawan

Kerajinan Ukiran Kabupaten Subang

Ardika Sulaeman $91-100$

Analisis Harga Saham dan Rata-Rata Abnormal Return Sebelum dan Sesudah Ex-Dividend Date (Studi pada Emiten Indeks Kompas-100)

Alvin Mulya Hidayati $101-107$

Pengaruh Manajemen Laba Akrual dengan Pendekatan Revenue Discretionary Model terhadap Kinerja Perusahaan Manufaktur di Bursa Efek Indonesia 


\title{
Pengaruh Upah dan Pengalaman Kerja terhadap Produktivitas Karyawan Kerajinan Ukiran Kabupaten Subang
}

\author{
Ardika Sulaeman \\ STIE Miftahul Huda Subang \\ Jl. Rancasari Dalam No B.33 Rancasari - Pamanukan Kp.41254 Subang \\ E-Mail: ardika.sulaeman@gmail.com
}

\begin{abstract}
Background of this research was the low productivity of the employees of wood-carving in Subang district. This study therefore aimed to determine the effect of work experience and wage on employee productivity. The research was conducted on the wood carving business employees through observation of 134 people from 20 wood-carving companies in Subang district. The results of this study indicate that there are positive effects of wage and work experience to work productivity either partially or simultaneously.
\end{abstract}

Keywords: employee productivity, wage, work experience, wood craved.

\begin{abstract}
ABSTRAK
Penelitian ini dilatarbelakangi oleh rendahnya produktivitas karyawan kerajinan mebel ukir di Kabupaten Subang. Dengan demikian penelitian ini bertujuan untuk mengetahui pengaruh upah dan pengalaman kerja terhadap produktivitas karyawan unit usaha mebel ukir di Kabuapaten Subang. Penelitian ini dilakukan terhadap karyawan usaha mebel ukiran kayu yang berjumlah 134 orang dari 20 perusahaan ukiran kayu yang ada di wilayah Kabupaten Subang. Hasil dari penelitian ini menunjukkan bahwa terdapat pengaruh positif upah dan pengalaman kerja terhadap produktivitas kerja baik secara parsial maupun simultan.
\end{abstract}

Kata Kunci: produktivitas karyawan, upah, pengalaman kerja, kerajinan ukiran. 


\section{PENDAHULUAN}

Produktivitas kerja karyawan merupakan faktor yang sangat penting dalam menunjang keberhasilan suatu usaha. Produktivitas yang tinggi akan sangat menguntungkan baik bagi pengusaha maupun bagi karyawannya terutama untuk kesejahterannya. Produktivitas juga mencerminkan etos kerja karyawan yang disana tercermin juga sikap mental yang baik. Dengan demikian, baik pengusaha maupun karyawan yang terlibat berupaya, untuk meningkatkan produktivitasnya, dengan berbagai kebijakan yang secara efisien mampu meningkatkan produktivitas karyawan.

Permasalahan awal yang penulis temukan dalam survei pendahuluan mengenai produktivitas usaha skala mikro kecil dan menengah (UMKM) di Kabupaten Subang adalah menurunnya produksi mebel ukir di Kabupaten Subang, berdasarkan pengamatan lebih lanjut, hal ini disebabkan oleh turunnya produktivitas karyawan mebel ukir tersebut. Mebel ukir merupakan produksi ungggulan Kota Subang pertama yang disusul dengan kerajinan anyam bambu, dodol nanas, dan keripik. Daerah pemasaran lokal meliputi Cikole dan Tangkuban perahu, pemasaran nasional meliputi Kalimantan dan Sumatera dan pemasaran luar negeri sampai ke negara Cina. Dari hasil penelitian pendahuluan secara acak pada usaha mebel di Kabupaten Subang, diperoleh produktivitas karyawan selama bulan Maret-Juni 2013 mengalami penurunan, hal ini tampak pada Tabel 1.

Dari data Tabel 1. berdasarkan penelitian pendahuluan, dapat dilihat bahwa produktivitas pada bulan Maret di lima usaha ukiran kayu tersebut sebesar 1,04 unit per tenaga kerja, selanjutnya menurun pada bulan Mei menjadi sebesar 0,95 unit per tenaga kerja dan dan menurun kembali pada Juni menjadi sebesar 0,93 unit per tenaga kerja. Sebagian besar barang yang diproduksi oleh usaha ukiran ini berasal dari pesanan. Penurunan ini banyak disebabkan oleh sulitnya mencari karyawan yang mampu membuat ukiran kayu dengan baik dan jumlah pengrajin kayu dan pengukir kayu semakin lama semakin berkurang (penelitian pendahuluan, 2013).

Karyawan yang mampu memproduksi dalam jumlah yang banyak dengan kualitas yang baik dalam kerajinan ukiran sangat dipengaruhi oleh lamanya pengalaman kerja, karena pekerjaan membuat mebel ukir banyak memerlukan keterampilan khusus. Keunggulan mebel Subang dibandingkan dengan daerah lain terletak pada teknik pembuatan yaitu dengan menggunakan teknik 'srek' yaitu teknik pengukiran dengan bantuan solder, sehingga memberikan kesan lebih alami jika dibandingkan dengan produk ukiran dari usaha kesil menengah di luar Kabupaten Subang, namun teknik ini sulit dilakukan oleh pengrajin kayu pada umumnya. Dalam hal ini semakin berpengalaman, biasanya hasil pekerjaan karyawan lebih banyak dan berkualitas.

Selain itu, kendala dalam usaha mebel ukir adalah harga bahan baku (kayu) yang langka dan mahal, maka biasanya pengusaha akan menekan biaya dengan memberikan upah yang murah bagi pekerja. Rata-rata upah per karyawan mebel ukir per bulan adalah Rp 900.000.00,-. Upah ini di bawah Upah Minimum Regional (UMR) Kabupaten Subang yaitu sebesar Rp 1.220.000,00,- (www.gajimu.com).

Dari beberapa literatur disebutkan bahwa banyak faktor yang dapat mempengaruhi produktivitas karyawan. Namun dalam penelitian ini hanya fokus pada variabel upah dan pengalaman kerja, karena variabel yang lain seperti (keamanan dan perlindungan, suasana kerja yang baik, promosi, dan pengembangan diri keorganisasian) yang merupakan isu keorganisasian, jenjang karir, dan risiko keselamatan kerja tidak terjadi pada usaha mebel ukir.

Menurut L. Greenberg dalam Sinungan (2008:12) mendefinisikan produktivitas sebagai perbandingan antara totalitas pengeluaran pada waktu tertentu dibagi totalitas masukan selama periode tersebut. Samuelson (1993:133) menyatakan bahwa produktivitas merupakan suatu konsep pengukuran rasio output total terhadap rata-rata input tertimbang. Sehingga berdasarkan pendapat para ahli tersebut dapat disimpulkan bahwa produktivitas adalah perbandingan antara jumlah output yang dihasilkan dengan jumlah sumber daya yang digunakan.

Dalam mengukur produktivitas, kita dapat mengartikan produktivitas total faktor produksi sebagai output per unit input total dari modal dan tenaga kerja, produktivitas tenaga kerja sebagai jumlah output per unit tenaga kerja, dan produktivitas modal sebagai output per unit modal. Produktivitas juga dapat diartikan sebagai rasio antara output terhadap input sumber daya yang dipakai. Maka jika dalam rasio tersebut sumber daya dimasukan seluruhnya untuk menghasilkan output, maka disebut dengan produktivitas total, namun jika yang dihitung sebagai masukan hanya faktor sumber daya tertentu saja maka disebut sebagai produktivitas parsial. 
Tabel 1. Produktivitas Rata-rata Karyawan pada Usaha Mebel Ukir

Kecamatan Pagaden Kabupaten SubangTahun 2013

\begin{tabular}{lccccc}
\hline Bulan & $\begin{array}{c}\text { Jumlah Perusahaan } \\
\text { Mebel Ukir (Unit) }\end{array}$ & $\begin{array}{c}\text { Jumlah Tenaga Kerja } \\
\text { (Orang) }\end{array}$ & $\begin{array}{c}\text { Jam Kerja } \\
\text { Per Hari }\end{array}$ & $\begin{array}{c}\text { Produksi } \\
\text { Per Bulan (Unit) }\end{array}$ & $\begin{array}{c}\text { Produktivitas Total } \\
\text { (Unit/org) }\end{array}$ \\
\hline Maret & 5 & 44 & 9 & 46 & 1,04 \\
April & 5 & 42 & 9 & 38 & 0,90 \\
Mei & 5 & 42 & 9 & 40 & 0,95 \\
Juni & 5 & 43 & 9 & 40 & 0,93 \\
\hline
\end{tabular}

Sumber: Data Pra Penelitian (Data Diolah)

Menurut Ricky W. Giffin (2003:213-214) produktivitas tenaga kerja pada dasarnya merupakan produktivitas parsial, karena hanya membagi output dengan satu jenis input, yaitu hanya tenaga kerja. Jadi, produktivitas tenaga kerja merupakan perbandingan antara total keluaran dengan masukan tenaga kerja. Produktivitas tenaga kerja dapat diukur dengan menggunakan masukan tenaga kerjanya per minggu, per tahun, atau per jam kerja. Sehingga produktivitas dapat diartikan sebagai perbandingan antara hasil keluaran yang diukur dalam kesatuan fisik dan nilai masukan tenaga kerja.

Banyak faktor yang mempengaruhi produktivitas tenaga kerja, menurut J. Rivianto (1985:4) berpendapat bahwa produktivitas tenaga kerja itu sendiri dipengaruhi oleh berbagai faktor baik yang berhubungan dengan tenaga kerja itu sendiri maupun faktor-faktor lainnya, seperti: keterampilan, gizi dan kesehatan, tingkat penghasilan, jaminan sosial, lingkungan dan iklim kerja, hubungan industri pancasila, teknologi, sarana produksi manajemen, dan kesempatan berprestasi.

Anoraga dalam Yuniarsih dan Suwatno (2009:159) menyebutkan bahwa faktor-faktor yang mempengaruhi produktivitas tenaga kerja adalah pekerjaan yang baik, upah yang baik, keamanan dan perlindungan dalam pekerjaan, penghayatan atas maksud dan makna pekerjaan, lingkungan atau suasana kerja yang baik, promosi dan perkembangan diri yang merasa sejalan dengan perkembangan perusahaan/ organisasi, merasa terlibat dalam kegiatan-kegiatan organisasi, pengertian dan simpati atas persoalanpersoalan pribadi, kesetiaan pimpinan pada si pekerja, dan disiplin kerja yang keras.

Berdasarkan uraian tersebut dapat dilihat bahwa salah satu faktor penting yang mempengaruhi produktivitas tenaga kerja yaitu upah yang diterima oleh para pekerja. Menurut Sukirno (2003:353) menyebutkan bahwa upah dalam teori ekonomi diartikan sebagai pembayaran yang diperoleh berbagai bentuk jasa yang disediakan dan diberikan oleh tenaga kerja kepada para pengusaha. Dengan demikian upah dapat diartikan sebagai balas jasa yang diterima oleh tenaga kerja setelah melakukan suatu pekerjaan. Dalam penelitian Sumarlin et al (2010) disebutkan teori upah efisiensi dari Cafferty (1990), yang menjelaskan bahwa produktivitas pekerja tergantung pada tingkat upah yang mereka terima. Tenaga kerja yang mendapatkan upah tinggi maka dia dapat memenuhi kebutuhan hidup dengan mengkonsumsi makanan yang bergizi badan menjadi sehat, dengan demikian dia bisa mengalokasikan waktu bekerjanya lebih tenang sehingga produktivitas kerja dapat ditingkatkan.

Faktor lain yang dapat mempengaruhi produktivitas tenaga kerja adalah pengalaman kerja. Seperti disebutkan dalam penelitian Fagbenle (2012) yang didalamnya menyebutkan bahwa salah satu faktor yang mempengaruhi produktivitas karyawan adalah berasal dari diri karyawannya atau yang disebut sebagai Human Factor, salah satunya adalah pengalaman kerja. Pengalaman kerja yang dikemukakan oleh Manulang (2005:15) adalah proses pembentukan pengetahuan dan keterampilan tentang metode suatu pekerjaan bagi para pegawai karena keterlibatan tersebut dalam pelaksanaan pekerjaannya. Pengalaman kerja merupakan faktor yang paling mempengaruhi dalam terciptanya pertumbuhan suatu usaha. Dengan tingginya pengalaman yang dimiliki oleh para pekerja akan menyebabkan tingginya pertumbuhan usaha tersebut. Penelitian yang memperlihatkan adanya hubungan positif antara pengalaman kerja dan produktivitas ditemukan pada penlitain yang dilakukan oleh Brown (1989) dan Acemoglu (1998). 
Berdasarkan penjelasan tersebut, maka dalam penelitian ini permasalahan yang akan dikaji adalah bagaimana gambaran produktivitas karyawan, upah karyawan, dan pengalaman kerja pada usaha mebel di Kabupaten Subang, serta apakah terdapat pengaruh pengalaman kerja dan upah yang diberikan kepada karyawan terhadap produktivitas karyawan baik secara simultan maupun parsial.

\section{METODE}

Metode yang digunakan dalam penelitian ini adalah survey explanatory, jenis penelitian yang digunakan adalah penelitian survei dengan sampel jenuh pada 20 pengusah ukiran kayu di Kecamatan Pagaden. Adapun objek penelitian pada penelitian ini adalah produktivitas, upah yang diperoleh karyawan dan lama kerja karyawan. Produktivitas karyawan diperoleh dari membandingkan antara output dan input yang digunakan dalam proses produksi. Upah diperoleh dari survei, dalam satuan uang yang diberikan pada tiap periode pengupahan, sedangkan pengalaman kerja diperoleh dari lama karyawan bekerja di usaha ukiran kayu.

Populasi dalam penelitian ini adalah seluruh usaha mebel ukir di Kabupaten Subang yang berjumlah 20 unit usaha, dengan jumlah karyawan total 134 orang. Sampel yang diambil digunakan sampel jenuh dalam artian seluruh karyawan digunakan sebagai responden dalam penelitian ini. Teknik analisis data yang digunakan adalah analisis parametrik dengan analisis jalur (Path Analysis). Uji hipotesis baik dilakukan secara parsial dengan uji-t maupun secara simultan dengan uji-F.

Hubungan antar variabel produktivitas karyawan dengan variabel tingkat upah dan pengalama kerja ini digambarkan sebagai berikut.

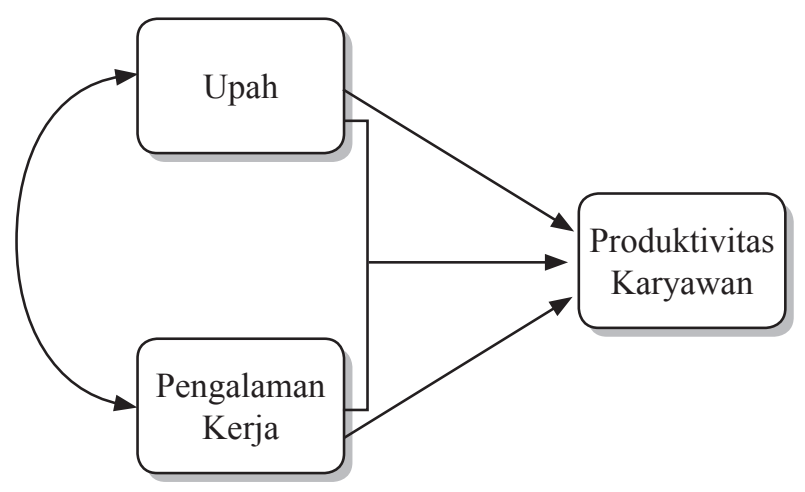

Gambar 1. Paradigma Penelitian
Berdasarkan paradigma penelitian tersebut, maka hipotesis dalam penelitian ini adalah (a) terdapat pengaruh upah dan pengalaman kerja terhadap produktivitas karyawan, (b) terdapat pengaruh upah terhadap produktivitas karyawan, dan (c) terdapat pengaruh pengalaman kerja terhadap produktivitas karyawan pada usaha mebel yang ada di wilayah Kabupaten Subang.

\section{HASIL}

\section{Produktivitas Karyawan ( $\mathrm{Y}$ )}

Produktivitas karyawan per unit merupakan perbandingan antara output dengan input tenaga kerja. Dalam hal ini output produk mebel ukir rata-rata per bulan adalah 10 sampai dengan 20 unit per bulan. Adapun produktivitas karyawan berkisar antara 1,08 sampai dengan 2,42 unit per karyawan per bulan. Satu unit berarti satu set mebel ukir yang sebagian besar terdiri dari satu set meja- kursi, satu set lemari pakaian, satu set rak, dan lain-lain. Hasil penelitian menungjukkan tingkat produktivitas karyawan mebel ukir terlihat pada Tabel 2. dan Gambar 2.

Tabel 2. Produktivitas Rata-rata Karyawan Mebel Ukir Per bulan Kabupaten Subang

\begin{tabular}{cccl}
\hline $\begin{array}{c}\text { Produktivitas } \\
\text { Rata-rata } \\
\text { Karyawan } \\
\text { Per Bulan }\end{array}$ & $\begin{array}{c}\text { Jumlah } \\
\text { Karyawan }\end{array}$ & Persentase & Kategori \\
\hline $1,08-1,36$ & 29 & 21.64 & Sangat Rendah \\
$1,35-1,61$ & 35 & 26.12 & Rendah \\
$1,62-1,87$ & 20 & 14.93 & Cukup \\
$1,89-2,15$ & 22 & 16.42 & Tinggi \\
$2,16-2,42$ & 28 & 20.90 & Sangat Tinggi \\
& 134 & 100.00 & \\
\hline
\end{tabular}

Sumber: hasil penelitian, 2013

Berdasarkan angka produktivitas yang diperoleh dari hasil penelitian, produktivitas dibagi menjadi 5 kategori yaitu sangat rendah, rendah, cukup, tinggi, dan sangat tinggi. Dari hasil penelitian, produktivitas karyawan dengan kategori rendah yaitu dengan tingkat produktivitas sebesar 1,35-1,61 mencakup 26,12\% dari total karyawan di usaha mebel Kabupaten Subang. Produktivitas karyawan adalah 1,35-1,61 artinya, seorang karyawan rata-rata dapat menyelesaikan 1,351,61 unit mebel per bulannya. Produktivitas karyawan rata-rata per bulan tertinggi adalah sebesar 2,42. 
Produktivitas Karyawan

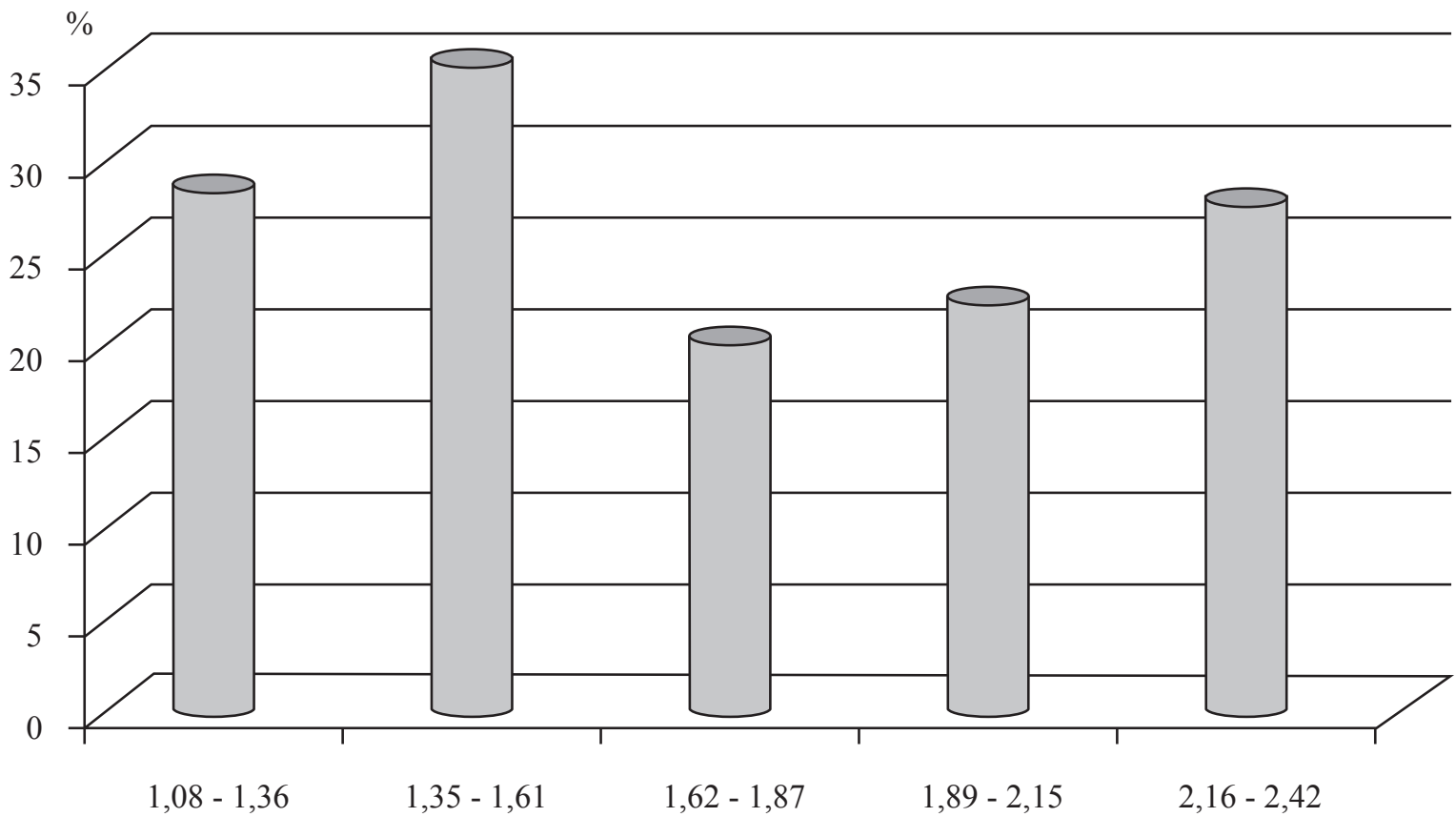

Gambar 2. Produktivitas Karyawan Mebel Ukir Kab. Subang

Rata-rata Upah Karyawan Mebel Ukir

Kab. Subang Per Hari

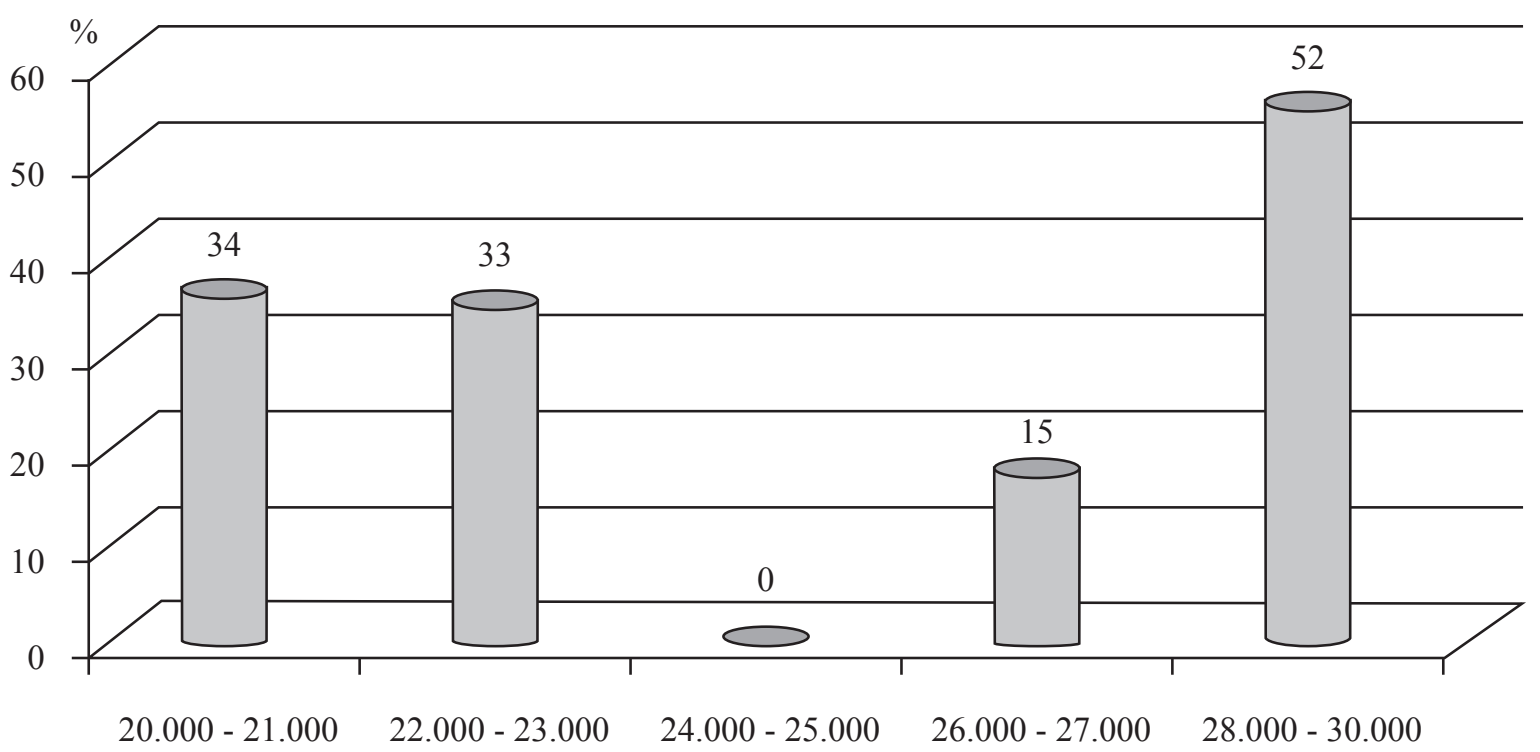

Gambar 3. Rata-rata Upah Karyawan Mebel Ukir Kab. Subang 


\section{Tingkat Upah $\left(X_{1}\right)$}

Upah merupakan suatu imbalan yang diterima para karyawan dari pemberi kerja atau atasan untuk suatu pekerjaan atau jasa yang telah dan akan dilakukan. Tingkat kesejateraan karyawan dapat diukur dari tinggi rendahnya upah yang diterima masing-masing karyawan.

Sistem pengupahan yang digunakan pada usaha ukiran kayu di Kabupaten Subang adalah upah hari kerja. Tabel 3. berikut memperlihatkan standar upah rata-rata untuk setiap jenis pekerjaan pada unit usaha ukiran kayu di Kabupaten Subang.

Tabel 3. Standar Upah Rata-rata

Berdasarkan Jenis Pekerjaan

\begin{tabular}{llc}
\hline No. & Jenis Pekerjaan & $\begin{array}{c}\text { Upah Rata-rata } \\
\text { Per Unit }\end{array}$ \\
\hline 1 & Desain ukiran & 30.000 \\
2 & Potong kayu & 7.500 \\
3 & $\begin{array}{l}\text { Penghalusan kayu (Sugu } \\
\text { dan ampelas) }\end{array}$ & 10.000 \\
4 & Mebelair & 20.000 \\
5 & Ukir & 20.000 \\
6 & Finishing & 10.000 \\
\hline
\end{tabular}

Sumber: hasil penelitian, 2013

Berdasarkan data standar upah tersebut, maka upah rata-rata yang diterima karyawan mebel ukiran Kabupaten Subang per hari dapat dilihat pada Tabel 4.

Tabel 4. Upah Rata-rata Setiap Karyawan Per hari Mebel Ukir Perhari

\begin{tabular}{cccl}
\hline $\begin{array}{c}\text { Upah Rata-rata } \\
\text { setiap Karyawan } \\
\text { Per Hari }\end{array}$ & $\begin{array}{c}\text { Jumlah } \\
\text { Karyawan }\end{array}$ & Persentase & Kategori \\
\hline $20.000-21.000$ & 34 & 25.37 & Sangat Rendah \\
$22.000-23.000$ & 33 & 24.63 & Rendah \\
$26.000-27.000$ & 15 & 11.19 & Tinggi \\
$28.000-30.000$ & 52 & 38.81 & Sangat Tinggi \\
Total & 134 & 100.00 & \\
\hline
\end{tabular}

Sumber: hasil penelitian, 2013

Berdasarkan data hasil penelitian tersebut, ratarata upah setiap karyawan per hari berkisar antara Rp 20.000,00,- sampai dengan Rp 30.000,00,-. Jika dihitung dari total jumlah karyawan, maka sebagian besar karyawan (52\%) menerima upah sebesar Rp $28.000,00$,- sampai dengan Rp 30.000,00,- per orang per hari atau $\mathrm{Rp} 800.000,00$,- sampai dengan $\mathrm{Rp}$ $900.000,00,-$ per orang per bulan. Upah karyawan mebel ukir di Kabupaten Subang terkategori tinggi dalam sektornya, namun angka ini masih di bawah UMR Kabupaten Subang tahun 2013 yaitu sebesar Rp 1.220.000,00,- per orang per bulan (dapat dilihat pada Gambar 3.).

\section{Pengalaman Kerja $\left(\mathbf{X}_{\mathbf{2}}\right)$}

Pengalaman kerja menunjukkan sejauh mana penguasaan seseorang terhadap bidang pekerjaan yang selama ini ditekuninya. Pada umumnya pengalaman kerja diukur dengan melihat seberapa lama waktu yang dihabiskan tenaga kerja pada suatu bidang pekerjaan tertentu. Karyawan yang mempunyai pengalaman yang lebih lama akan mempunyai keterampilan yang lebih tinggi, sehingga produktivitasnya pun lebih tinggi dibandingkan dengan tenaga kerja yang baru memiliki sedikit pengalaman. Berikut ini disajikan data pengalaman kerja karyawan mebel ukir Kabupaten Subang yang diperoleh dari hasil penelitian.

Berdasar data hasil penelitian tersebut, sebagian besar lama kerja karyawan adalah satu sampai dengan dua tahun. Sebagian besarkaryawan telah bekerja lebih dari satu instansi. Umumnya perekrutan karyawan di usaha mebel ukir didasarkan pada pengalaman kerja, karena produk mebel ukir banyak membutuhkan keterampilan khusus terutama untuk pekerjaan mengukir. Karyawan yang dianggap terampil dalam mengukir adalah karyawan yang bekerja minimal dua tahun di bidangnya.

\section{Analisis data}

Analisis data yang digunakan dalam penelitian ini adalah analisis jalur. Hasil pengolahan data dengan mentode analisis jalur yang memperlihatkan bagaimana pengaruh pengalaman kerja dan tingkat upah dapat dilihat dari Tabel 5. berikut.

Tabel 5. Hasil Pengollahan Data dengan Analisis Jalur

\begin{tabular}{llrrrr}
\hline Model & R & R Square & $\begin{array}{c}\text { Adjusted } \\
\text { R Square }\end{array}$ & $\begin{array}{r}\text { Std. Error of } \\
\text { the Estimate }\end{array}$ \\
\hline 1 & & $.965(\mathrm{a})$ & .931 & .930 & .10765 \\
\hline a & Predictors: (Constant), LAMA, UPAH & &
\end{tabular}




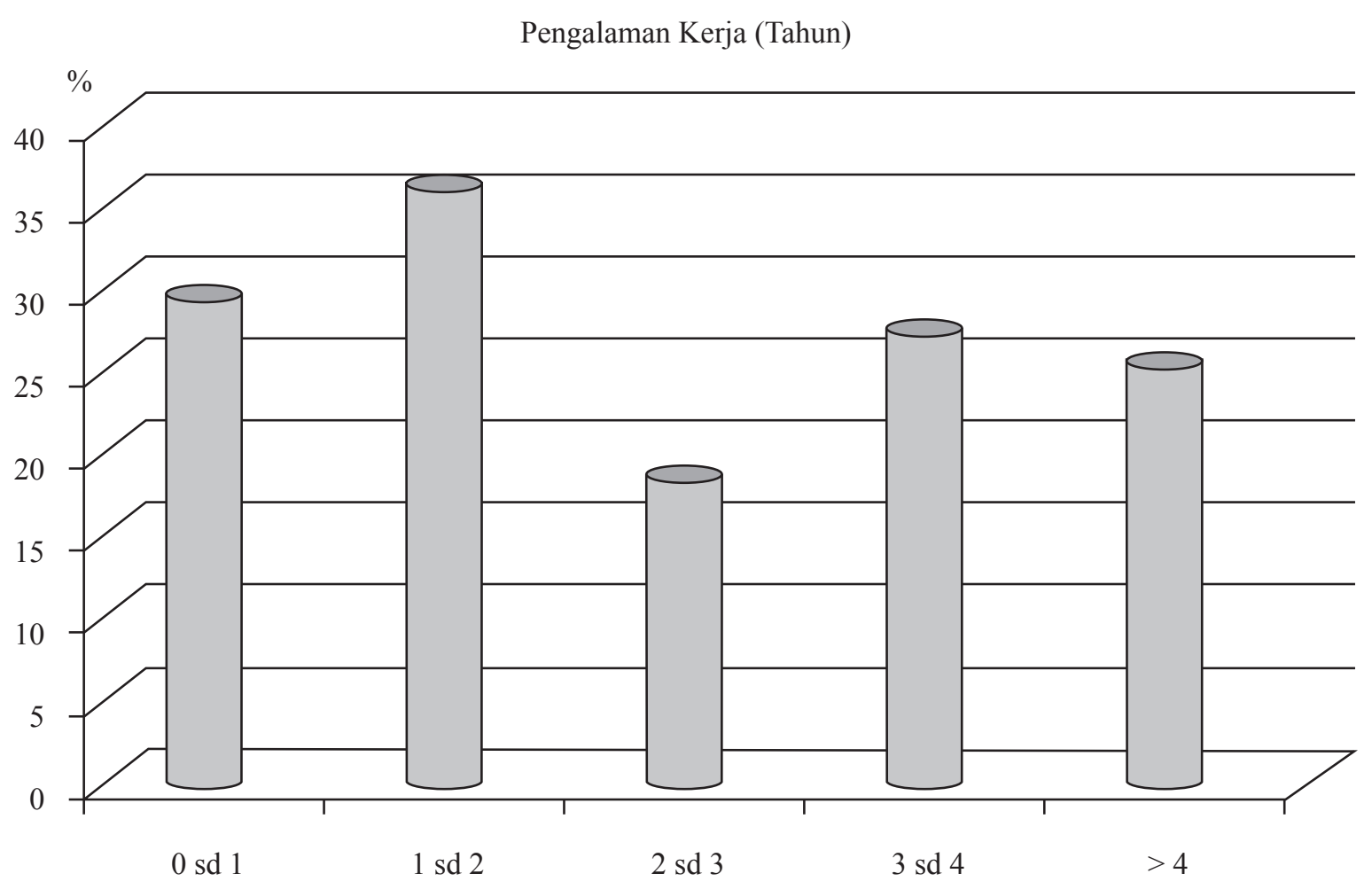

Gambar 4. Pengalaman Kerja Karyawan Mebel Ukir

Kab. Subang

Dari Tabel 5. diperoleh angka R-Square $\left(\mathrm{R}^{2}\right)$ adalah sebesar 0,931. Angka tersebut menggambarkan besarnya pengaruh pengalaman kerja dan upah terhadap produktivitas kerja. Hal ini berarti $93,12 \%$ produktivitas karyawan pada unit usaha mebel ukir di Kabupaten Subang dipengaruhi oleh upah dan pengalaman kerja.

\section{Pengujian Pengaruh Simultan}

Untuk mengetahui signifikansi pengaruh seluruh variabel bebas upah dan pengalaman kerja secara simultan terhadap produktivitas karyawan, maka dilakukan uji hipotesis dengan menggunakan angka F-hitung. Berdasarkan hasil penghitungan diperoleh hasil F-satistik sebagai berikut.

Tabel 6. F-Statistik Hasil Perhitungan

\begin{tabular}{llrrrrr}
\hline Model & & $\begin{array}{c}\text { Sum of } \\
\text { Squares }\end{array}$ & df & $\begin{array}{c}\text { Mean } \\
\text { Square }\end{array}$ & F & Sig. \\
\hline 1 & Regression & 20.418 & 2 & 10.209 & 881.047 & $.000(\mathrm{a})$ \\
& Residual & 1.518 & 131 & .012 & & \\
& Total & 21.936 & 133 & & & \\
\hline
\end{tabular}

a Predictors: (Constant), LAMA, UPAH

b Dependent Variable: PRODUKTIVITAS
Berdasarkan Tabel 6. angka taraf signifikansi adalah 0,00 atau lebih kecil dari ,05 maka Ho ditolak dan $\mathrm{H} 1$ diterima, artinya terdapat pengaruh simultan upah dan pengalaman kerja terhadap produktivitas karyawan pada unit usaha mebel ukir di Kabupaten Subang.

\section{Pengujian Pengaruh Parsial}

Untuk mengetahui pengaruh parsial masingmasing variabel bebas upah dan pengalaman kerja secara parsial terhadap produktivitas karyawan, maka diuji dengan menggunakan uji-t. Tabel 7.menunjukkan hasil perhitungan t-statistik dalam penelitian ini.

Tabel 7. Hasil Perhitungan Uji-t

\begin{tabular}{|c|c|c|c|c|c|c|}
\hline \multirow{2}{*}{\multicolumn{2}{|c|}{ Model }} & \multicolumn{3}{|c|}{$\begin{array}{l}\text { Unstandardized Standardized } \\
\text { Coefficients Coefficients }\end{array}$} & \multirow[t]{2}{*}{$\mathbf{T}$} & \multirow[t]{2}{*}{ Sig. } \\
\hline & & B & $\begin{array}{l}\text { Std. } \\
\text { Error }\end{array}$ & Beta & & \\
\hline \multirow[t]{3}{*}{1} & (Constant) & -.061 & .103 & & -.594 & .554 \\
\hline & UPAH & $4.920 \mathrm{E}-05$ & .000 & .470 & 7.875 & .000 \\
\hline & LAMA & .220 & .026 & .513 & 8.592 & .000 \\
\hline
\end{tabular}

a Dependent Variable: PRODUKTIVITAS 
Pengaruh Upah dan lama kerja terhadap produktivitas secara parsial diuji dengan menggunakan uji-t, dalam hal ini t-tabel pada $\alpha=0,05$ df $134-2=132$ adalah 1,976 . Pengaruh upah terhadap produktivitas diuji dengan membandingkan t-tabel dengan t-hitung, dalam hal ini t-hitung upah adalah 7,875 dengan demikian, $\mathrm{t}$ hitung $>\mathrm{t}$ tabel, maka kesimpulan yang diambil adalah terdapat pengaruh upah secara parsial terhadap produktivitas karyawan.

Pengaruh lama kerja (pengalaman kerja) terhadap produktivitas diuji dengan membandingkan t-hitung sebesar 8,595 dengan t-tabel sebesar 1,976. Dalam hal ini t-hitung lebih besar dari t-tabel, maka terdapat pengaruh pengalaman kerja terhadap produktivitas karyawan.

Hubungan Upah karyawan dan pengalaman kerja dilakukan dengan mengkorelasikan variabel upah dengan produktivitas kerja, hal ini dapat dilihat dari Tabel 8.

Tabel 8. Koefisien Korelasi

\begin{tabular}{llrr}
\hline & & UPAH & \multicolumn{2}{c}{ LAMA } \\
\hline UPAH & Pearson Correlation & 1 & $.923(* *)$ \\
& Sig. (2-tailed) &. & .000 \\
& $\mathrm{~N}$ & 134 & 134 \\
LAMA & Pearson Correlation & $.923\left(^{* *}\right)$ & 1 \\
& Sig. (2-tailed) & .000 &. \\
& $\mathrm{~N}$ & 134 & 134 \\
\hline
\end{tabular}

** Correlation is significant at the 0.01 level (2-tailed)

Berdasarkan perhitungan diperoleh angka korelasi antara variabel upah dan pengalaman kerja sebesar 0,923. Untuk menaksir angka tersebut, digunakan kriteria sebagai berikut.

Tabel 9. Kriteria Korelasi

\begin{tabular}{ll}
\hline \multicolumn{1}{c}{ Nilai Koefisien Korelasi } & \multicolumn{1}{c}{ Kriteria Korelasi } \\
\hline $0-0,25$ & Korelasi sangat lemah \\
$>0,25-0,5$ & Korelasi cukup \\
$>0,5-0,75$ & Korelasi kuat \\
$>0,75-1$ & Korelasi sangat kuat
\end{tabular}

Korelasi sebesar 0,923 mempunyai maksud hubugan antara variabel upah dan pengalaman kerja yang sangat kuat dan searah dengan angka signifikansi 0,00 (signifikan).
Berdasarkan hasil pengolahan data seperti dijelaskan sebelumnya, maka dapat diperoleh persamaan struktural untuk diagram jalur dan diagram jalur dalam penelitian ini sebagai berikut:

$\mathrm{Y}=-0.061+0,47 \mathrm{X}_{1}+0,513 \mathrm{X}_{2}+\varepsilon$

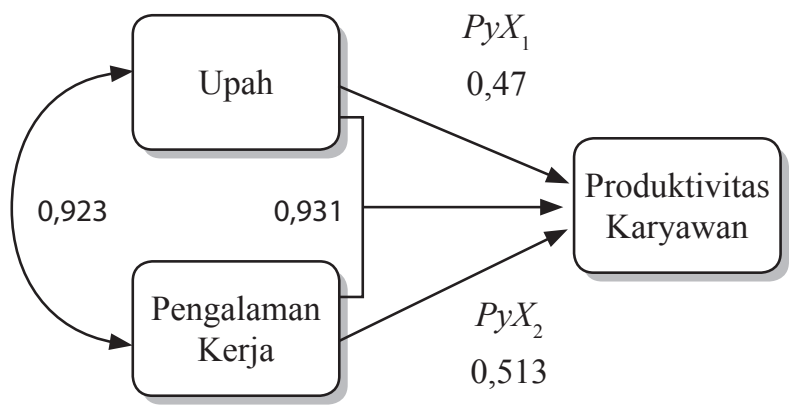

Gambar 5. Diagram Jalur Penelitian

\section{Pengaruh Langsung dan Tidak Langsung Antar Variabel}

Pengaruh langsung dalam model ini terdiri atas pengaruh upah terhadap produktivitas dan pengaruh pengalaman kerja terhadap produktivitas karyawan serta Pengaruh tidak langsung variabel upah terhadap produktivitas melalui pengalaman kerja dan pengaruh tidak langsung varaibel pengalaman kerja terhadap produktivitas melalui upah diperlihatkan pada Tabel 10.

\section{PEMBAHASAN}

\section{Pengaruh Tingkat Upah $\left(\mathrm{X}_{1}\right)$ terhadap Produktivitas $\operatorname{Kerja}(\mathrm{Y})$}

Hasil analisis data menunjukan bahwa ada pengaruh yang signifikan antara variabel tingkat upah terhadap variabel produktivitas kerja, hasil analisis regresi yang diperoleh dari output regresi, terdapat pengaruh positif antara variabel tingkat upah terhadap produktivitas kerja karyawan mebel ukir di Kab. Subang.

Berdasarkan analisis tersebut menunjukkan bahwa tingkat upah sangat berpengaruh terhadap produktivitas kerja. Menurut George A. A. Kerlof dan Ronal G. Ehrenberg dalam Priadana (2010:48) menyebutkan bahwa pemberian upah yang tinggi kepada para pekerja akan meningkatkan produktivitas pekerja. Dalam penelitian yang dilakukan oleh Sumarlin dan kawan-kawan (2010) membuktikan bahwa peningkatan upah di Indonesia dapat meningkatkan produktivitas pekerja. 
Tabel 10. Pengaruh Langsung dan Pengaruh Tidak Langsung

\begin{tabular}{|c|c|c|}
\hline & Pengaruh Langsung & Pengaruh Tidak Langsung \\
\hline \multirow[t]{2}{*}{ Hasil Analisis Jalur } & $\begin{array}{l}\text { - Pengaruh langsung upah terhadap } \\
\text { produktivitas karyawan }\left(\operatorname{PyX}_{1}\right)=0,47\end{array}$ & $\begin{array}{l}\text { Pengaruh tidak langsung upah terhadap produktivitas melalui } \\
\text { pengalaman kerja }\left(X_{1} \rightarrow X_{2} \rightarrow Y\right)=0,923^{*} 0,513=0,473\end{array}$ \\
\hline & $\begin{array}{l}\text { - Pengaruh langsung pengalaman kerja } \\
\text { terhadap produktivitas }\left(\operatorname{PyX}_{2}\right)=0,513\end{array}$ & $\begin{array}{l}\text { Pengaruh tidak langsung pengalaman kerja terhadap } \\
\text { produktivitas karyawan melalui upah }\left(X_{1} \rightarrow X_{2} \rightarrow Y\right)=0,923 \\
*^{*} 0,47=0,433\end{array}$ \\
\hline Kesimpulan & $\begin{array}{l}\text { Hal ini berarti upah mempengaruhi } \\
\text { produktivitas karyawan sebesar } 47 \% \\
\text { dan pengalaman kerja mempengaruhi } \\
\text { produktivitas karyawan sebesar } 51,3 \% \text {. }\end{array}$ & $\begin{array}{l}\text { Hal ini berarti upah mempengaruhi produktivitas karyawan } \\
\text { melalui pengalaman kerja sebesar } 47,3 \% \text { dan pengalaman } \\
\text { kerja mempengaruhi produktivitas karyawan melalui upah } \\
\text { sebesar } 43,3 \% \text {. }\end{array}$ \\
\hline
\end{tabular}

Upah sebagai salah satu fungsi penting dalam manajemen sumber daya manusia dan pada dasarnya upah adalah balas jasa dalam bentuk uang yang diterima karyawan sebagai seorang karyawan yang memberikan konstribusi dari statusnya sebagai seorang karyawan yang memberikan konstribusi dalam mencapai tujuan perusahaan, atau dapat juga dikatakan sebagai bayaran tetap yang diterima seseorang karena kedudukannya dalam perusahaan. Upah dapat berfungsi sebagai stimulus bagi karyawan, adaya upah yang tinggi, maka karyawan akan bersemangat dalam bekerja, maka produktivitasnya akan meningkat karena pekerja merasa diperlakukan secara adil oleh pengusaha, dengan begitu mereka akan bekerja lebih giat.

Hubungan positif antara tingkat upah dengan produktivitas karyawan juga dikemukankan oleh Leibenstein dalam Priadana (2010:68) yang menjelaskan bahwa produktivitas tenaga kerja mempunyai hubungan yang positif dengan tingkat upah yang dibayar oleh perusahaan. Sehingga dia menyarankan di negara berkembang tingkat upah yang relatif lebih tinggi akan meningkatkan kesehatan dan standar gizi, yang selanjutnya secara tidak langsung akan meningkatkan produktivitas tenaga kerja. Penelitian mengenai terdapat hubungan positif upah dengan produktivitas berlaku pada karyawan mebel di Jepara (Widyaningsih, 2012), pada perusahaaan sepatu (Herdiansyah, 2011) dan industri kecap di Kecamatan Pati (Lestari, 2011). Dengan demikian hubungan antar variabel ini dapat menggeneralisir untuk perusahaan atau industri lain selain perusahaan mebelair.

\section{Pengaruh Pengalaman Kerja $\left(\mathrm{X}_{2}\right)$ terhadap Produktivitas Kerja (Y)}

Hasil analisis data menunujukan bahwa ada pengaruh yang signifikan antara variabel pengalaman kerja terhadap variabel produktivitas kerja, hasil analisis regresi yang diperoleh dari output regresi, terdapat pengaruh positif antara variabel pengalaman kerja terhadap produktivitas kerjakaryawan ukiran kayu Kabupaten Subang.

Hal ini sesuai dengan apa yang dikemukakan oleh John Locke yang dikutip oleh Sedarmayanti bahwa pengalaman merupakan faktor utama dalam perkembangan seseorang, sedangkan pengalaman hanya mungkin diperoleh dalam hubungan lingkungannya (Sedarmayanti, 2001:68). Dalam penelitiannya Weiss (1994) menjelaskan bahwa dari sampel penelitiannya, pengalaman kerja pekerja yang diperoleh melalui melalui sistem learning-by-doing, maka diharapkan pengalaman tersebut akan dapat mempengaruhi peingkatan produktivitas pekerja.

Hal ini berarti pula bahwa jiwa dan kemampuan seseorang akan lebih mapan, apabila orang tersebut sebelumnya telah merasakan kegiatan yang sama dalam waktu relatif lama. Karena biasanya pengalaman akan lebih merasuk ke dalam kehidupan kejiwaan seseorang, sehingga akan meninggalkan suatu kesan yang mendalam, dibandingkan dengan pengetahuan yang hanya diperoleh melalui pendidikan formal atau non formal. Semakin lama seorang pekerja melakukan pekerjaannya, maka akan semakin terampil. Keterampilan yang tinggi akan berdampak positif terhadap kinerjanya, seperti waktu yang diperlukan untuk menyelesaikan pekerjaannya 
menjadi semakin cepat, selain itu kualitas hasil pekerjaannya juga akan semakin baik. Hal ini sejalan dengan hasil penelitian Haddad et al. (2012) pada pada industri kesehatan, yang menunjukkan bahwa pekerja yang berpengalaman lebih cepat dan lebih baik dalam mengerjakan pekerjaannya daripada pekerja yang tidak berpengalaman.

\section{KESIMPULAN}

Gambaran produktivitas karyawan di usaha mebel ukiran di Kabupaten Subang sebagian besar dalam kondisi relatif rendah dengan jumlah unit produksi 1,06-1.18 unit/set per bulan per karyawan dengan upah berkisar pada Rp 28.000,- sampai dengan Rp 30.000,- per hari per karayawan dan pengalaman kerja karyawan sebagian besar selama 0-3 tahun.

Hasil penelitian ini menunjukkan bahwa terdapat pengaruh positif baik secara parsial maupun simultan antara upah dan pengalaman kerja terhadap produktivitas karyawan pada unit usaha mebel ukir di Kabupaten Subang. Adanya pengaruh yang signifikan antara tingkat upah dan pengalaman kerja terhadap produktivitas karyawan mengindikasikan bahwa untuk meningkatkan produktivitas karyawan pada usaha mebel ukir Kabupaten Subang, pengusaha melakukan sistem pengupahan yang lebih menstimulus peningkatan jumlah produksi misalnya perbaikan sistem upah per unit per karyawan, perluasan lokasi pemasaran sehingga dapat meningkatkan pesanan dan pada akhirnya akan meningkatkan produksi dan keuntungan perusahaan. Dengan peningkatan keuntungan perusahaan, pengusahan dapat memberikan pelayanan yang lebih baik lagi bagi karyawannya agar mereka dapat lebih produktif.

\section{DAFTAR PUSTAKA}

Acemoglu, D. \& Pischke, J.-S. 1998. Why Do Firms Train ? Theory and Evidence. Quarterly Journal of Economics, 113: 79-119.

Brown, J.N. 1989. Why do wages increase with tenure? On-The-Job Training and Life-Cycle Wage Growth Observed Within Firms. American Economic Review, 79: 971-991.
Fagbenle, Olabosipo I., Lawal Phillip O., and Omuh, Igartius O. 2012. The Influence of Training on Bricklayers' Productivity in Nigeria. International Journal of Management Sciences and Business Research, 1(7).

Griffin, Ricky W. 2003. Managemet. New York: HoughtonMiffin Company.

Haddad, T.,H., and Jaaron, A.A.M. 2012. The Applicability of Total Productive Maintenance for Healthcare Facilities: an Implementation Methodology. International Journal of Business, Humanities and Technology, 2(2).

Herdiansyah, Rizki. 2011. Pengaruh Pengalaman Kerja dan Tingkat Upah terhadap Produktivitas Pekerja di UD. Farley's Kota Mojokerto. diunduh dari www.academia.edu.

Lestari, Ratih Widi. 2011. Pengaruh Upah, Tingkat Pendidikan dan Teknologi Terhadap produktivitas Tenaga Kerja pada Industri Kecap Di Kecamatan Pati Kab. Pati. Jurusan Ekonomi Fakultas Ekonomi Universitas Negeri semarang.

Manulang, M. 2005. Dasar-Dasar Manajemen. Yogyakarta: Gajah Mada Univ. Press

Priadana, Sidik. 2010. Analisis Faktor Penentu Keberhasilan serta Dampak dari Kelompok Usaha Bersama di Jawa Barat. Trikonomika, 9(2): 7886.

Sedarmayanti. (2001). Sumber Daya Manusia dan Produktivitas Tenaga Kerja. Bandung: Ilham Jaya.

Sumarlin, Syarief, Ritonga, Sirojuzilam. 2010. Analisis Hubungan Tingkat Upah Tinggi Terhadap Produktivitas di Indonesia. Jurnal Mepa Ekonomi USU.

Sukirno, Sadono. 2003. Pengantar Ekonomi Mikro. Jakarta: Rajawali Press.

Sinungan, Muchdarsyah. 2003. Produktivitas Apa dan Bagaimana. Jakarta: Bumi Aksara.

Weiss, Andrew. 1994. Productivity Changes without Formal Training. University of Chicago Confrence.

Widyaningsih, Nesti . 2012. Pengaruh Pengalaman Kerja, Upah, dan Disiplin Kerja terhadap Produktivitas Kerja Karyawan CV Duta Jepara. Skripsi Fakultas Ekonomi Universitas Negeti Yogyakarta. 